O. Kuznietsov ${ }^{1}$, V. Karlov ${ }^{1}$, O. Kolomiitsev ${ }^{2}$, K. Sadovyi ${ }^{1}$, O. Biesova ${ }^{1}$

${ }^{1}$ Ivan Kozhedub Kharkiv National Air Force University, Kharkiv, Ukraine

${ }^{2}$ National Technical University «Kharkiv Polytechnic Institute», Kharkiv, Ukraine

\title{
THE INFLUENCE OF STATISTICAL CHARACTERISTICS OF THE FLUCTUATIONS OF THE RADIATION SIGNAL INITIAL PHASES ON THE ACCURACY OF THE MEASUREMENT AERODYNAMIC OBJECT RADIAL VELOCITY
}

\begin{abstract}
The article deals with the estimation of radial velocity when using a coherent packet of radio pulses regarding the case of the presence of correlated fluctuations of the initial phases in the reflected from the aerodynamic object pulses. The subject of the research is the accuracy of measuring the frequency of the received packet for the case of concerted processing without taking into account the phase fluctuations of its radio pulses. The purpose is a numerical analysis of the influence of the statistical characteristics of the fluctuations of the received pack's initial phases on the decrease in the accuracy of measuring the radial velocity of the aerodynamic object. The task: to estimate the possible values of fluctuation constituent middling quadratic error of measuring of radial speed of aerodynamic object. Consideration is given to the assumption that an additive mixture of deflected signal and uncorrelated Gaussian noise is input to the radar receiver. It is considered that the phase fluctuations of the received packet are distributed according to the normal law with zero mean, and the correlation of phase fluctuations with the increase of the interval between the packet radio pulses decreases according to the alternating law. Methods used: methods of probability theory and mathematical statistics. The following results are obtained: the accuracy of frequency measurement of the pack had been estimated in the presence of correlated phase fluctuations of its radio pulses. Conclusions. The results indicate that for modern radars in the conditions of regular measurement the accuracy of estimating the frequency of the packet of radio pulses is much more influenced by the statistical characteristics of the phase fluctuation than the signal-to-noise ratio. Due to the phase fluctuations of the radio pulses of the received packet, the mean-square error (MSE) of radial velocity measurement of the aerodynamic object is able to exceed the values determined by the requirements for coherent pulse radar.
\end{abstract}

Keywords: coherent pulse radar; packet of radio pulses; phase fluctuations; radial velocity aerodynamic object; Gaussian noise; radar surveillance; optimization efficiency.

\section{Introduction}

Formulation of the problem. Improvements and development of modern aerodynamic objects of radar surveillance, performance of their tasks at low and limiting low altitudes cause increasing requirements for their detection and tracking facilities. The increase in the maneuverability of aerodynamic objects makes it necessary to evaluate radars of different classes of range derivatives to the aerodynamic object with maximum accuracy. The determination of the radial velocity of the aerodynamic object during the primary time-frequency processing of the radar signal is realized in coherent pulse radars, which use a coherent packet of radio pulses as the probing signal. The degree of coherence of a packet determines the duration of its regular phase structure and, as a result, the radial velocity resolution and the accuracy of measuring the radial velocity of an air object. The real conditions for the propagation and reflection of a radar signal could substantially limit its temporal coherence and the quality of its timefrequency processing.

These conditions include the influence of atmospheric heterogeneities [1-3], Doppler objective noise [4-6] and the reflection of radio waves from the earth's surface with complicated terrain [7-9].

The degree of coherence of the packet determines the duration of its regular phase structure and, as a result, the measure of the frequency resolution and the accuracy of measuring the frequency of the specified radar signal. In modern coherent-pulse radars that provide radar surveillance of maneuvering aerodynamic objects in a complicated aerodynamic object and interference condition, algorithms for digital coherent accumulation of the received packet radio signal are implemented. Therefore, it is of practical use to estimate the error of measuring the frequency of the received pack depending on the statistical characteristics of the phase fluctuations of its radio pulses.

The estimation of the possible decrease in the accuracy of the radial velocity measurement of the aerodynamic object due to the signal's phase fluctuations will allow to determine the conditions for optimization of its processing.

Analysis of recent research and publications. A considerable amount of work is devoted to radar surveillance of aerodynamic objects and the measurement of their coordinates and motion parameters under complicated conditions.

The distortions of the phase structure of the radar signal have a different nature. Phase fluctuations due to an atmospheric heterogeneities and the peculiarities of the use of radio engineering systems under the conditions of their influence are described in $[1,7,10$ 12]. In addition, phase distortions of the received signal, which are due to the complex shape of the aerodynamic object and its ability to perform sudden maneuver, cause the wandering of its radar center and, as a result, the appearance of velocity's noise of the aerodynamic object $[1,4,5,13,14]$. If radar surveillance is implemented for aerodynamic objects moving at low angles of location, and due to the multipath propagation of the radar signal, additional phase distortions are appeared $[4,7,8,15-26]$. 
There is $[28,29]$ the method for calculating the error of the packet's frequency arising due to the influence of phase fluctuations of its radio pulses.

As shown in $[30,31]$, the possible values of the measurement errors of the time-frequency parameters of the radar signal resulting from its phase distortions are capable of exceeding the allowable radar values of different wavelength ranges. The assumptions about the statistical characteristics of the reflected signals are confirmed by the results of the experimental investigation, which were elucidated in [32].

The purpose of the article is a numerical analysis of the influence of the statistic characteristics of the initial phase fluctuations of the radio pulses for the received coherent pack on the decrease of the accuracy of the radial velocity measurement of the aerodynamic object.

\section{Basic material}

The radial velocity of the aerodynamic object is estimated according to the expression $[1,2]$ :

$$
V_{r}=\frac{\lambda}{4 \pi} \Omega,
$$

where $\Omega=2 \pi F_{D}$ - the cyclic Doppler shift of the frequency; $F_{D}-$ Doppler frequency; $\lambda$ - the wavelength of the radar signal.

It is assumed that the received realization is the sum of the reflected of the packet radio pulses from the aerodynamic object and the internal noise:

$$
y(t, \Omega)=x(t, \Omega)+n(t),
$$

where $y(t, \Omega)$ - realization of the received oscillation; $x(t, \Omega)$ - realization of a useful signal; $n(t)$ realization of internal Gaussian noise.

A useful signal is a coherent packet of radio pulses with random amplitude and initial phase whose complex amplitude is described by expression:

$$
\dot{X}(t, \Omega)=b \sum_{i=1}^{n} \dot{X}_{i}(t, \Omega) \exp [j(\beta)],
$$

where $\dot{X}_{i}(t, \Omega)$ - the complex amplitude of the i-th radio impulse; $b$ - random amplitude of the radio signal, which is distributed according to Rayleigh's law; $\beta$ - the random initial phase of the radio signal, which is distributed according to a equable law; $i-$ the radio pulse number that counted from the beginning of the packet; $n$ - the number of radio pulses in the packet.

According to [1] it is determined that estimating the shift of the frequency of the packet of radio pulses could be realized by finding the argument of the maximum natural logarithm of the likelihood ratio:

$$
\widehat{\Omega}=\arg \max \ln \ell(\Omega) .
$$

where $\ell(\Omega)$ - the likelihood ratio as a function of the measured parameter.

It is determined in [1] that the likelihood ratio for a coherent signal with a uniformly distributed random phase and a random amplitude which distributed according to the Rayleigh law, as a result of the statistical averaging by the random parameters $b$ and $\beta$ has the form:

$$
\ell(\Omega)=\frac{1}{1+q^{2} / 2} \exp \frac{q^{2} / 2}{2\left(1+q^{2} / 2\right)}\left|Z_{n}(\Omega)\right|^{2},
$$

where $q^{2}-$ the signal-to-noise ratio for power; $\left|Z_{n}(\Omega)\right|^{2}$ - the square of the module of the normalized complex weight integral as a function of the measured parameter.

In the conditions of regular measurement $\left(q^{2}>>1\right)$, equality is valid:

$$
\left|Z_{n}(\Omega)\right|=\left|Z_{H}\left(\vec{\Phi}_{n}, \vec{\Phi}_{o}\right)\right| \approx q \rho\left(\vec{\Phi}_{S} \vec{\Phi}_{o}\right)=q \rho(\Omega),
$$

where $\vec{\Phi}_{s}=\left\|\Phi_{s i}\right\|^{T} \quad(i=1,2, \ldots, n)$ - vector of observed values of the initial phases of the packet radio pulses; $\vec{\Phi}_{o}=\left\|\Phi_{o i}\right\|^{T}-$ vector of the expected values of the initial phases of the packet radio pulses; $\rho\left(\vec{\Phi}_{s}, \vec{\Phi}_{o}\right)=\rho(\Omega)$ - a normalized mismatch function by the phase of the observed and expected radio signal.

Taking into account (6) the likelihood ratio (5) is taking the form when $q^{2}>1$ :

$$
\ell(\Omega) \approx\left(2 / q^{2}\right) \cdot \exp \left(q^{2} \rho^{2}(\Omega) / 2\right) .
$$

As shown in [28], in the case of a coherent pack with a constant period of radio pulses, the square of the normalized mismatch function by the frequency is described by the expression:

$$
\begin{gathered}
\rho^{2}(\Omega)=1-\frac{1}{2} \sum_{i=1}^{n} \sum_{j=1}^{n} \xi_{i} \xi_{j}\left(\Phi_{i}-\Phi_{j}\right)^{2}- \\
-\frac{1}{2} T^{2} \Omega^{2} \sum_{i=1}^{n} \sum_{j=1}^{n} \xi_{i} \xi_{j}(i-j)^{2}+ \\
+T \Omega \sum_{i=1}^{n} \sum_{j=1}^{n} \xi_{i} \xi_{j}(i-j)\left(\Phi_{i}-\Phi_{j}\right),
\end{gathered}
$$

where $\Omega=\omega-\omega_{0}$ - the mismatch between the observed $\omega$ and expected $\omega_{0}$ cyclic frequencies of the pulse packet; $i, j-$ pulse numbers that are counted from the beginning of the packet; $\Phi_{i}, \Phi_{j}$ - observed values of the initial phase of the $i$-th and $j$-th radio pulses accordingly; $\xi_{i}=\frac{Z_{i}}{Z_{\Sigma}} ; Z_{i}=\frac{1}{2}\left|\int_{-\infty}^{\infty} \dot{Y}_{i}(t) \dot{X}_{i}^{*}(t) d t\right|$ - module of the signal part of the complex correlation integral for the i-th radio pulse; $\dot{\mathrm{Y}}_{i}(t)-$ complex envelope of the received i-th radio pulse; $\dot{\mathrm{X}}_{i}^{*}(t)-$ complex conjugate envelope of the reference voltage during the processing of the i-th radio pulse; $\mathrm{Z}_{\Sigma}=\sum_{i=1}^{n} \mathrm{Z}_{i} ; T-$ period of packet radio pulses. 
For a symmetric amplitude distribution of radio pulses in the packet $\xi_{i}=\xi_{n+1-i}$, using the expression (8) into (7), computing logarithm and leaving only the dependent on the measured parameters subtrahends, we obtain an expression for sufficient statistics:

$$
\begin{aligned}
S(\Omega)= & \ln \ell(\Omega)=-\frac{q^{2}}{2}\left\{\frac{T^{2}}{2} \Omega^{2} \sum_{i=1}^{n} \sum_{j=1}^{n} \xi_{i} \xi_{j}(i-j)^{2}-\right. \\
& \left.-T \Omega \sum_{i=1}^{n} \sum_{j=1}^{n} \xi_{i} \xi_{j}(i-j)\left(\Phi_{i}-\Phi_{j}\right)\right\} .
\end{aligned}
$$

Estimation and dispersion of the error of estimation of the frequency of a packet of radio pulses is obtained according to the method of maximum likelihood [1] by the expressions:

$$
\begin{gathered}
\frac{d S(\Omega)}{d \Omega}=0 \text { when } \Omega=\widehat{\Omega}, \\
\frac{1}{\sigma_{\Omega}^{2}}=-\frac{d^{2} \ln \ell(\Omega)}{d \Omega^{2}}=-\frac{d^{2} S(\Omega)}{d \Omega^{2}} \text { when } \Omega=\widehat{\Omega},
\end{gathered}
$$

where $\ln \ell(\Omega)$ - the natural logarithm of the likelihood ratio (7) or its sufficient statistics $S(\Omega) ; \widehat{\Omega} \quad-$ estimation of frequency of the packet radio pulses.

After a one-time and two-time differentiation by the measured parameter of sufficient statistics (9), the estimation and dispersion of the error of frequency estimation in the next form are obtained:

$$
\begin{gathered}
\widehat{\Omega}=\sum_{j=1}^{m} \xi_{j}(2 j-1) R_{j} / T \sum_{j=1}^{m} \xi_{j}(2 j-1)^{2}, \\
\frac{1}{\sigma_{\Omega}^{2}}=\frac{q^{2} T^{2}}{2} \sum_{j=1}^{m} \xi_{j}(2 j-1)^{2}
\end{gathered}
$$

where $R_{j}$ - the difference of the $\mathrm{j}$-th initial phases of the symmetric pair radio pulses; $m$ - the number of pairs of radio pulses symmetrical about the center of the packet.

If the packet of radio pulses has a rectangular envelope $\left(\xi_{i}=1 / n\right)$, expressions (12) and (13) could be converted to the form:

$$
\begin{gathered}
\widehat{\Omega}=\frac{3}{m\left(4 m^{2}-1\right) T} \sum_{j=1}^{m}(2 j-1) R_{j}, \\
\frac{1}{\sigma_{\Omega}^{2}}=\frac{q^{2}\left(4 m^{2}-1\right)}{12} T^{2} .
\end{gathered}
$$

Random error of frequency measurement caused by fluctuations of initial phases of packet pulses could be represented by the expression:

$$
\Delta \Omega=\frac{3}{m\left(4 m^{2}-1\right) T} \sum_{j=1}^{m}(2 j-1) \Delta R_{j},
$$

where $\Delta R_{j}$ - fluctuations in the phase difference of the $\mathrm{j}$-th symmetric pair of radio pulses.
The dispersion of this error is determined by the expression:

$$
\sigma_{\Omega \phi л}^{2}=\frac{9}{m^{2}\left(4 m^{2}-1\right)^{2} T^{2}}\left\langle\left[\sum_{j=1}^{m}(2 j-1) \Delta R_{j}\right]^{2}\right\rangle,
$$

where ( $(-$ the operation of statistical averaging.

The dispersion of the total measurement error of the frequency of the packet of radio pulses is determined by the sum of the error dispersion $\sigma_{\Omega}^{2}$ which conditioned by the influence of the internal noise of the receiving device and the error dispersion $\sigma_{\Omega f l}^{2}$ (17) caused by the phase fluctuations of the radio pulses:

$$
\sigma_{\Sigma}^{2}=\sigma_{\Omega}^{2}+\sigma_{\Omega f l}^{2} .
$$

It is believed that the phase fluctuations of the received packet radio pulses are distributed according to the normal law with zero mean, and the correlation of phase fluctuations of the adjacent radio pulses of the packet decreases according to the alternating law [1].

The realization of the statistical averaging (17) allows to obtain the expression of the dispersion of the total error of measuring the frequency of a packet of radio pulses at the alternating correlation function of phase fluctuations:

$$
\begin{gathered}
\sigma_{\Sigma}^{2}=\frac{12}{q^{2} T^{2}\left(4 m^{2}-1\right)}+\frac{18 \sigma_{\varphi}^{2}}{m^{2} T^{2}\left(4 m^{2}-1\right)^{2}} \times \\
\times\left[\sum_{k=1}^{m}(2 k-1)^{2}\left(1-(-a)^{(2 k-1)}\right)+2 \times\right. \\
\left.\times \sum_{k=1}^{m-1} \sum_{i=1}^{m-k}(-a)^{i}(2 k-1)(2 k+2 i-1)\left(1-(-a)^{(2 k-1)}\right)\right],
\end{gathered}
$$

where $\sigma_{\varphi}^{2}$ - dispersion of phase fluctuations; $a$ - the correlation coefficient of phase fluctuations of adjacent radio pulses of the packet.

There is a graph of the dependency of the square product of the measurement MSE of the frequency of a packet for ten radio pulses and their period $\left(\sigma_{\Sigma} T\right)^{2}$ on the signal-to-noise ratio in power $q^{2}$ when $\mathrm{a}=0,99$ (Fig. 1, a) and the correlation coefficient of phase fluctuations (Fig. 1, b) when $q^{2}=1000$. Graphs are obtained for different values of phase fluctuation dispersion $\sigma_{\varphi}^{2}=0,01 ; 0,1 ; 1 ; 10 \mathrm{rad}^{2}$.

The results are shown in Fig. 1, and indicate that, under the conditions of regular measurement (when $q^{2}>>1$ ), the accuracy of measuring the frequency of the packet of radio pulses mainly depends on the statistical characteristics of phase fluctuations than on the magnitude of the signal-to-noise ratio.

Increasing the dispersion of phase fluctuations by an order of magnitude has almost no effect on changing the magnitude of the error dispersion of the 
measurement of the frequency of the packet radio pulses for the small values $\left(\sigma_{\varphi}^{2}=0,01 \ldots 10 \mathrm{rad}^{2}\right)$. Increasing this dispersion by an order of magnitude $\left(\sigma_{\varphi}^{2}=1 \ldots 10 \mathrm{rad}^{2}\right)$, which can occur in practical cases, leads to an increase in the dispersion of the error measurement of the frequency of the packet radio pulses by an order of magnitude and more.

These results were obtained for the alternating correlational function of phase fluctuations, with a decrease in the inter-pulse correlation coefficient by only $1 \%(a=0,99)$.

The graphs in Fig. 1, b indicate that, as the dispersion of phase fluctuations $\left(\sigma_{\varphi}^{2}=0,01 \ldots 10 \mathrm{rad}^{2}\right)$ increases, the effect of their inter-pulse correlation coefficient on the measurement error of the frequency of the packet radio pulses increases. Most significantly, this effect occurs at large dispersion of phase fluctuations $\left(\sigma_{\varphi}^{2}=1 \ldots 10 \mathrm{rad}^{2}\right)$, which can indeed take place under the real conditions of the use of the radar. $\left(\sigma_{\Sigma}^{2} \mathrm{~T}\right)^{2}$

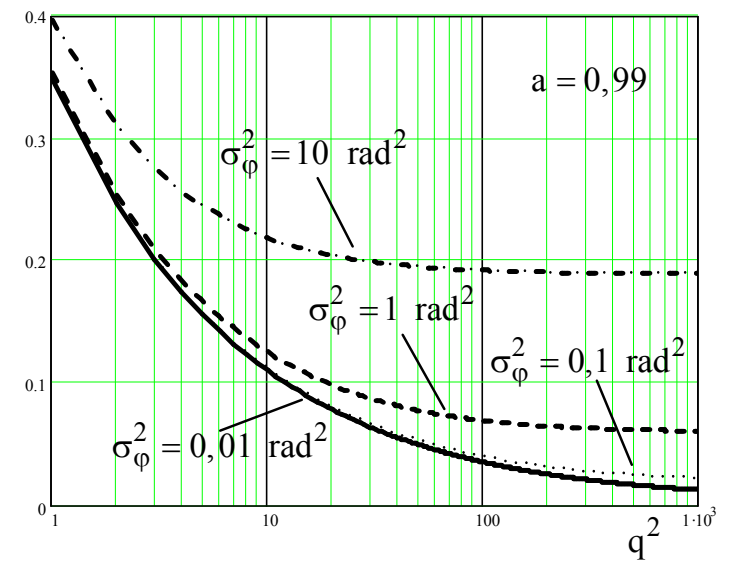

$$
\left(\sigma_{\Sigma}^{2} \mathrm{~T}\right)^{2}
$$

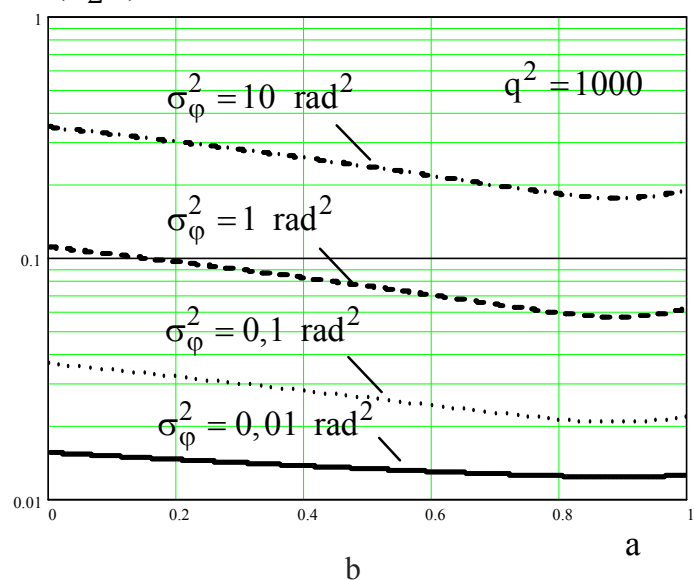

Fig. 1. Dispersion of measurement error of the frequency of the packet radio pulses in the absence of consideration of phase fluctuations

For a packet of pulses with rectangular envelope and pair number of pulses, the dispersion error of the measured parameter $\Omega$ in the presence of only the internal noise of the receiving device is estimated according to expression (15) and has the form:

$$
\sigma_{\Omega}^{2}=\frac{12}{q^{2}\left(4 m^{2}-1\right) T^{2}} .
$$

For phase fluctuations of the radio pulses of a received pack with an oscillating correlation function, the dispersion of the measurement error of the parameter $\Omega$ by the presence of only phase fluctuations is estimated according to the expression obtained in [28]:

$$
\begin{gathered}
\sigma_{\Omega f l}^{2}=18 \sigma_{\varphi}{ }^{2} /\left(m^{2}\left(4 m^{2}-1\right)^{2} T^{2}\right) \times \\
\times\left[\sum_{j=1}^{m}(2 j-1)^{2}\left(1-\exp \left(-\frac{T}{\tau}(2 j-1)\right) \cos ((2 j-1) \gamma T)\right)+2 \times\right. \\
\times \sum_{l=1}^{m-j} \exp \left(-\frac{T}{\tau} l\right) \sum_{j=1}^{m-1}(2 j-1)(2 j+2 l-1) \times \\
\times\left(\cos (j \gamma T)-\exp \left(-\frac{T}{\tau}(2 j-1)\right) \cos ((2 j+l-1) \gamma T)\right),(21)
\end{gathered}
$$

where $\tau-$ the interval of the correlation of the phase fluctuation; $\gamma$ - oscillation frequency of the phase correlation coefficient.

The corresponding components of the MSE of radial velocity measurement of the aerodynamic object can be calculated according to the expressions:

$$
\begin{gathered}
\sigma_{v}=(\lambda / 4 \pi) \cdot \sigma_{\Omega}, \\
\sigma_{v f l}=(\lambda / 4 \pi) \cdot \sigma_{\Omega f l} .
\end{gathered}
$$

It is of practical benefit to obtain the possible values of the MSE components of the measurement of the aerodynamic object's radial velocity in the signal-tonoise ratio $q^{2}=1000$, for the cases of coherent accumulation of short $n=8$, medium $n=16$ and long $n=32$ packets of radio pulses.

For the case of the radio waves propagation in a randomly-heterogeneous environment, in $[1,2]$ the magnitudes of the dispersion of the phase fluctuations of a radio signal $\sigma_{\varphi}^{2}$ which passed through the perturbed Earth troposphere are given. The interval of correlation of phase fluctuations can be $\tau=0,1 \ldots 1 \mathrm{~s}$.

The heterogeneities of the troposphere $100 \mathrm{~m}$ in size can cause phase fluctuations with dispersion $\sigma_{\varphi}^{2}=1,74 \mathrm{rad}$ at $\lambda=0,1 \mathrm{~m}$ for the surveillance radar at the range of detection of aerodynamic objects over $200 \mathrm{~km}$.

The troposphere heterogeneities of $100 \mathrm{~m}$ size can cause phase fluctuations with dispersion $\sigma_{\varphi}^{2}=4,8 \ldots 9,7$ at $\lambda=3 . . .5 \mathrm{~cm}$ for the tracking radar at detection ranges of aerodynamic objects $50 \ldots 150 \mathrm{~km}$.

For the given data, the expressions (22) and (23) can be used to calculate the component of the measurement MSE of the aerodynamic object's radial velocity which are conditioned by the internal noise and phase fluctuations of the received packet radio pulses accordingly for $n=8,16$ and 32 . The results of the 
calculations of the components of the measurement MSE of the radial velocity for the surveillance radar are shown in table 1 .

The results of the calculations of the components of the measurement MSE of the radial velocity for the tracking radar are shown in table 2 .

The obtained results indicate that the values of the components of the measurement MSE of the radial velocity which are conditioned by the phase fluctuations of the radio pulses of the received packet, can several times exceed the components which are conditioned by the influence of the internal noise of the radar receiving device.

\section{Table 1 - Components of the measurement MSE of the} radial velocity for the surveillance radar, $\mathrm{m} / \mathrm{s}$

\begin{tabular}{|c|c|c|}
\hline$n$ & $\sigma_{v}$ & $\sigma_{v f l}$ \\
\hline 8 & $0,08 \ldots 0,18$ & $0,5 \ldots 0,76$ \\
\hline 16 & $0,04 \ldots 0,09$ & $0,36 \ldots 0,54$ \\
\hline 32 & $0,02 \ldots 0,05$ & $0,26 \ldots 0,38$ \\
\hline
\end{tabular}

Table 2 - Components of the measurement MSE of the radial velocity for the tracking $\mathrm{radar}, \mathrm{m} / \mathrm{s}$

\begin{tabular}{|c|c|c|}
\hline$n$ & $\sigma_{v}$ & $\sigma_{\text {vfl }}$ \\
\hline 8 & 0,66 & $1,85 \ldots 6,9$ \\
\hline 16 & 0,33 & $1,3 \ldots 4,82$ \\
\hline 32 & 0,16 & $0,91 \ldots 3,4$ \\
\hline
\end{tabular}

In addition to the effect of troposphere heterogeneities, the effect of aerodynamic object Doppler noise and multipath propagation causes an additional increase of the fluctuation component of the measurement MSE of the radial velocity to several units of $\mathrm{m} / \mathrm{s}$ or more. Moreover, the phase distortions of the radar signal significantly exerts influence on the operation of the tracking radar, causing the danger of disruption of the aerodynamic object from the autotracking in the range and radial velocity.

\section{Conclusions and Directions of Further Research}

There are fluctuations in the initial phases of the received packet pulses with a normal distribution law and alternating correlation function when a coherent-pulse radar is operating in real conditions. These fluctuation can greatly reduce the quality of the time-frequency processing of a radar signal. The accuracy of radial velocity measurement essentially depends on the statistical characteristics of phase fluctuations dispersion and correlation, which values determines the conditions and the usefulness of optimizing the timefrequency processing of the received packet radio pulses.

Areas of further research are: evaluation of influence of casual phase distortions radio of локационного signal on quality of accompaniment of aerodynamic object.

\section{REFERENCES}

1. Shirman, Ya.D. (1999), Radio electronic systems, Z.A.O. "MAKVISC”, Moscow, 828 p.

2. Shifrin, Ya.S. (1970), Statistical antenna theory issues, Sov. radio, Moscow, 383 p.

3. Karlov, V.D., Petrushenko, N.N., Chelpanov, V.V. and Kvitkin, K.P. (2010), "The influence of the propagation medium of radio waves in the coastal direction in measuring the angular coordinates of the radar targets", Scientific Works of Kharkiv Air Force University, No. 3 (25), pp. 51-53.

4. Skolnik, M. (1976), Radar Reference Guide, Sov. radio, Moscow, 456 p.

5. Ostrovityanov, R.V. and Basalov, F.A. (1982), The statistical theory of radar extended targets], Radio and communication, Moscow, $232 \mathrm{p}$.

6. Karlov, V.D., Leonov, I.G., Prisyazhny, A.E. and Lukovskiy, O.Ya. (2006), "Detection of aerodynamic targets in the conditions of noise and passive interference with a wide Doppler spectrum", Information Processing Systems, No. 9 (58), pp. 34-36.

7. Krasyuk, N.P. (1988), "The influence of the troposphere and underlying surface on the radar's work", Radio and communication, Moscow, $223 \mathrm{p}$.

8. Kotov, A.F. (1992),"Influence of reflections from a laying surface on the process of location objects", Teory and practice of synchronization systems, pp. 4-8.

9. Karlov, V.D., Minervin, N.N., Petrushenko, N.N. and Lukashuk, E.V. (2008), "Influence of inhomogeneities of radar station's position on the effectiveness of suppressing external interference when locating of the overwater targets", Navigation and communication control systems, No. 4 (8), pp. 34-36.

10. Petrushenko, M.M. (2009), "Features of the use of radio systems of the Air Force in unstable hydrometeorological conditions and natural meteorological phenomena", Navigation and communication control systems, No. 2 (10), pp. 54-57.

11. Karlov, V.D., Minervin, N.N., Petrushenko, N.N., Lukashuk, E.V. and Lukovskiy, O.Ya. (2008), "Influence of fluctuations of the noise wave front on the efficiency of its suppression by the correlation compensator in radio-technical systems of coastal basing", Information Processing Systems. No. 7 (74), pp. 87-93.

12. Karlov, V.D., Kucher, D.B., Strutsinskiy, O.V. and Lukashuk, O.V. (2016), "On the issue of measuring the range of lowaltitude target during its radiolocation within the tropospheric waveguide over the sea", Science and Technology of the Air Force of Ukraine, No. 3 (24), pp. 98-101.

13. Karlov, V.D., Kondratenko, A.P., Sheygas, A.K. and Sytnyk, Yu.B. (2014), "On the question of measuring the Doppler frequency of a signal is reflected from a target is located outside the horizon above the sea", Science and Technology of the Air Force of Ukraine, No. 1 (14), pp. 115-117.

14. Karlov, V.D., Petrushenko, M.M., Pevtsov, G.V. and Nos, A.I. (2012), "Features of the measurement of the radial component of the target velocity, which is located at small angles of the place above the sea", $8^{\text {th }}$ Scientific Conference of Ivan Kozhedub Kharkiv Air Force University: New technologies - for air space protection, April 18-19, 2012, Kharkiv, p. 295.

15. Karlov, V.D., Petrushenko, N.N. and Nos, A.I. (2012), "Using the phase method for optimizing the measurement of the radial component of the target velocity is located outside the radio horizon above the sea", $12^{\text {th }}$ Scientific Conf.: The creation and modernization of weapons and military equipment in modern condition, September 6-7, 2012, Theodosius, p. 198.

16. Donets V., Kuchuk N., Shmatkov S. Development of software of e-learning information system synthesis modeling process. Advanced Information Systems, Vol. 2, No 2. P. 117-121. DOI: https://doi.org/10.20998/2522-9052.2018.2.20. 
17. Kuchuk G., Nechausov S., Kharchenko, V. Two-stage optimization of resource allocation for hybrid cloud data store. International Conference on Information and Digital Technologies. Zilina, 2015. P. 266-271. DOI: http://dx.doi.org/10.1109/DT.2015.7222982

18. Merlac V. Resourses Distribution Method of University e-learning on the Hypercovergent platform / V. Merlac, S. Smatkov, N. Kuchuk, A. Nechausov // Conf. Proc. of 2018 IEEE $9^{\text {th }}$ International Conference on Dependable Systems, Service and Technologies. DESSERT'2018. Ukraine, Kyiv, May 24-27, 2018. - P. 136-140. - URL :http://dx.doi.org/ 10.1109/DESSERT.2018.8409114

19. Kuchuk N. Method for calculating of R-learning traffic peakedness / N. Kuchuk; O. Mozhaiev, M. Mozhaiev; H. Kuchuk // 2017 4th International Scientific-Practical Conference Problems of Infocommunications Science and Technology, PIC S and T 2017. - 2017. - P. 359 - 362. URL : http://dx.doi.org/10.1109/INFOCOMMST.2017.8246416

20. Nechausov A., Mamusuĉ I., Kuchuk N. Synthesis of the air pollution level control system on the basis of hyperconvergent infrastructures. Advanced Information Systems, Vol. 1, No 2. P. 21 - 26. DOI: https://doi.org/10.20998/2522-9052.2017.2.04

21. Yaloveha, V., Hlavcheva, D. and Podorozhniak, A. (2019), "Usage of convolutional neural network for multispectral image processing applied to the problem of detecting fire hazardous forest areas", Advanced Information Systems, Vol. 3, No 1, pp. 116-120, DOI: https://doi.org/10.20998/2522-9052.2019.1.19

22. Mozhaev O. Multiservise network security metric / O. Mozhaev, H. Kuchuk, N. Kuchuk, M. Mozhaev, M. Lohvynenco // IEEE Advanced information and communication technologies-2017. Proc. of the 2th Int. Conf. - Lviv, 2017. - P. 133-136. DOI: https://doi.org/10.1109/AIACT.2017.8020083

23. Kuchuk G., Kovalenko A., Komari I.E., Svyrydov A., Kharchenko V. Improving big data centers energy efficiency: Traffic based model and method. Studies in Systems, Decision and Control, vol 171. Kharchenko, V., Kondratenko, Y., Kacprzyk, J. (Eds.). Springer Nature Switzerland AG, 2019. Pp. 161-183. DOI: http://doi.org/10.1007/978-3-030-00253-4_8

24. Svyrydov, A., Kuchuk, H., Tsiapa, O. (2018), "Improving efficienty of image recognition process: Approach and case study", Proceedings of 2018 IEEE 9th International Conference on Dependable Systems, Services and Technologies, DESSERT 2018, pp. 593-597, DOI: http://dx.doi.org/10.1109/DESSERT.2018.8409201

25. Ruban, I. Redistribution of base stations load in mobile communication networks / I. Ruban, H. Kuchuk, A. Kovalenko // Innovative technologies and scientific solutions for industries. -2017 . - No 1 (1) - P. 75-81. DOI : https://doi.org/10.30837/2522-9818.2017.1.075.

26. Kovalenko, A. and Kuchuk H. (2018), "Methods for synthesis of informational and technical structures of critical application object's control system”, Advanced Information Systems, Vol. 2, No. 1, pp. 22-27, DOI: https://doi.org/10.20998/25229052.2018.1.04

27. Karlov, V.D., Petrushenko, N.N. and Nos, A.I. (2012), "Using the phase method for optimizing the measurement of the radial component of the target acceleration above the sea", $12^{\text {th }}$ Scientific Conferencey: The creation and modernization of weapons and military equipment in modern condition, September 6-7, 2012, Theodosius, p. 210.

28. Minervin, N.N. and Kuznetsov, A.L. (2001), "Errors of measurement of radial velocity and radial acceleration of the target, due to the neglect of fluctuations of the phases of the burst pulses", Aerospace and Technology, No. 22, pp. 288-294.

29. Karlov, V.D., Besova, O.V., Oleshchuk, M.M. and Petrushenko, M.M. (2014), "About the influence of the propagation mechanism of radio waves on the location of targets in a tropospheric radio waveguide above the sea", $10^{\text {th }}$ Scientific Conf. of I. Kozhedub Kharkiv Air Force University: New technologies - for air space protection, April 9-10, 2014, Kharkiv, p. 254.

30. Minervin, M.M., Kuznietsov, O.L. and Tarshin, V.A. (2006), "Limit the accuracy of measuring the radial velocity of the target due to the conditions of propagation, reflection and processing of the radar signal", Scientific Works of Kharkiv Air Force University, No. 3 (9), pp. 116-118.

31. Karlov, V.D., Oleshchuk, M.M., Pevtsov, G.V. and Misaylov, V.L. (2014), "The results of experimental studies of the locations of low-altitude targets that fly over the sea surface", $3^{\text {th }}$ International STC NTU KhPI: Information problems of the theory of acoustic radio electronic and telecommunication systems IPST, 2014, Kharkiv, p. 35.

32. Karlov, V.D., Rodyukov, A.O. and Pichugin, I.M. (2015), ,’'Statistical characteristics of radar signals are reflected from local objects in conditions of abnormal refraction", Science and Technology of the Air Force of Ukraine, No. 4 (21), pp. 71-74.

33. Kuznietsov, O.L, Kolomiitsev, O.V., Sadovyi, K.V. (2017), "Distinction after way distance РЛС with the synthesized aerial by a grate in the conditions of influence of not homogeneity atmosphere", Collection of scientific works Ivan Kozhedub Kharkiv Air Force University, Kharkiv, No. 2(51), pp. 130-133.

34. Aloshin, G.V., Kolomiytsev, A.V. (2015), "Optimal choice of parameters of radio-location signals on the conditional criterion of a maximum of economic efficiency", The Informatively-managing systems are on a railway transport, Kharkiv, No. 6, pp. 3-7.

Надійшла (reviewed) 25.03.2020

Прийнята до друку (accepted for publication) 06.05.2020

\section{ВідОмості ПРо Авторів / AвоUT тHE AUTHORS}

Кузнєцов Олександр Леонідович - кандидат технічних наук, доцент, професор кафедри фізики та радіоелектроніки Харківського національного університету Повітряних Сил імені Івана Кожедуба, Харків, Україна;

Oleksandr Kuznietsov - Candidate of Technical Sciences, Associate Professor, Professor of Physics and Radio Electronics Department; Ivan Kozhedub Kharkiv National Air Force University, Kharkiv, Ukraine;

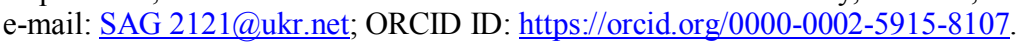

Карлов Володимир Дмитрович - доктор технічних наук, професор, завідувач кафедри фізики та радіоелектроніки Харківського національного університету Повітряних Сил імені Івана Кожедуба, Харків, Україна;

Vladimir Karlov - Doctor of Technical Sciences Professor Head of Physics and Radio Electronics Department, Ivan Kozhedub Kharkiv National Air Force University, Kharkiv, Ukraine; e-mail: Karlov@ukr.net; ORCID ID: https://orcid.org/0000-0002-1043-684X. 
Коломійцев Олексій Володимирович - доктор технічних наук, старший науковий співробітник, професор кафедри обчислювальної техніки та програмування, Національний технічний університет «ХПІ», Харків, Україна;

Oleksii Kolomiitsev - Doctor of Technical Sciences, Senior Research, Professor of Computer Science and Programming Department, National Technical University «Kharkiv Polytechnic Institute», Kharkiv, Ukraine; e-mail: Alexus k@ukr.net; ORCID ID: https://orcid.org/0000-0001-8228-8404.

Садовий Костянтин Віталійович - кандидат технічних наук, доцент, заступник начальника кафедри Харківського національного університету Повітряних Сил імені Івана Кожедуба, Харків, Україна;

Kostiantyn Sadovyi - Candidate of Technical Sciences, Associate Professor, Deputy Chief of the Department of Ivan Kozhedub Kharkiv National Air Force University, lieutenant colonel, Kharkiv, Ukraine; e-mail: 971sadovyi@gmail.com; ORCID ID: https://orcid.org/0000-0003-2703-9696.

Бссова Оксана Василівна - кандидат технічних наук, старший науковий співробітник Наукового центру Повітряних Сил Харківського національного університету Повітряних Сил імені Івана Кожедуба, Харків, Україна;

Oksana Biesova - Candidate of Technical Sciences, Senior Researcher of Air Force Science Centre of Ivan Kozhedub Kharkiv National Air Force University, Kharkiv, Ukraine; e-mail: bytko75@ukr.net; ORCID ID: https://orcid.org/0000-0001-7744-1339.

\title{
Вплив статистичних характеристик флуктуацій початкових фаз радіолокаційного сигналу
} на точність вимірювання радіальної швидкості аеродинамічного об'єкту

О. Л. Кузнєцов, В. Д. Карлов, О. В. Коломійцев, К. В. Садовий, О. В. Бєсова

Анотація. В статті розглядаються питання оцінювання радіальної швидкості при використанні когерентної пачки радіоімпульсів стосовно випадку наявності у відбитих від аеродинамічного об'єкту радіоімпульсах корельованих флуктуацій початкових фаз. Предметом вивчення є точність вимірювання частоти пачки для випадку погодженої обробки без урахування фазових флуктуацій iї радіоімпульсів. Метою $є$ чисельний аналіз впливу статистичних характеристик флуктуацій початкових фаз радіоімпульсів прийнятої пачки на зниження точності вимірювання радіальної швидкості аеродинамічного об'єкту. Завдання: оцінити можливі значення флуктуаційної складової середньоквадратичної похибки вимірювання радіальної швидкості аеродинамічного об'єкту. Розгляд проводиться в припущенні, що на вхід приймального пристрою радіолокаційної станції (РЛС) надходить адитивна суміш відбитих від аеродинамічних об'єктів сигналів i некорельованого гаусового шуму. Передбачається, що фазові флуктуації радіоімпульсів прийнятої пачки розподілені за нормальним законом 3 нульовим середнім, а кореляція фазових флуктуацій зі збільшенням інтервалу між радіоімпульсами пачки убуває за знакозмінним законом. Використовувані методи: теорії ймовірності та математичної статистики. Отримані наступні результати. Проведено оцінювання точності вимірювання частоти пачки при наявності корельованих фазових флуктуацій їі радіоімпульсів. Висновки. Отримані результати свідчать про те, що для сучасних РЛС, в умовах регулярного вимірювання, на точність оцінювання частоти пачки радіоімпульсів в значно більшому ступені впливають статистичні характеристики флуктуацій фаз, чим відношення сигнал-шум. Внаслідок фазових флуктуацій радіоімпульсів прийнятої пачки, середньоквадратична похибка вимірювання радіальної швидкості аеродинамічного об'єкту здатна перевищувати значення, які визначаються вимогами до когерентно-імпульсних РЛС. Подальший напрямок досліджень полягає у оцінюванні впливу випадкових фазових спотворень радіолокаційного сигналу на якість супроводження аеродинамічного об'єкту.

Ключові слова: когерентно-імпульсна радіолокаційна станція; пачка радіоімпульсів; фазові флуктуації; радіальна швидкість аеродинамічного об'єкту; гаусовий шум; радіолокаційне спостереження; ефективність оптимізації.

\section{Влияние статистических характеристик флуктуаций начальных фаз радиолокационного сигнала на точность измерения радиальной скорости аэродинамического объекта}

\author{
А. Л. Кузнецов, В. Д. Карлов, А. В. Коломийцев, К. В. Садовый, О. В. Бесова
}

Ан нотация. В статье рассматриваются вопросы оценивания радиальной скорости при использовании когерентной пачки радиоимпульсов применительно к случаю наличия в отраженных от аэродинамического объекта радиоимпульсах коррелированных флуктуаций начальных фаз. Предметом изучения является точность измерения частоты пачки для случая согласованной обработки без учета фазовых флуктуаций ее радиоимпульсов. Целью является численный анализ влияния статистических характеристик флуктуаций начальных фаз радиоимпульсов принятой пачки на снижение точности измерения радиальной скорости аэродинамического объекта. Задача: оценить возможные значения флуктуационной составляющей среднеквадратической ошибки измерения радиальной скорости аэродинамического объекта. Рассмотрение проводится в предположении, что на вход приемного устройства радиолокационной станции (РЛС) поступает аддитивная смесь отраженных от аэродинамических объектов сигналов и некоррелированного гауссово шума. Предполагается, что фазовые флуктуации радиоимпульсов принятой пачки распределены по нормальному закону с нулевым средним, а корреляция фазовых флуктуаций с увеличением интервала между радиоимпульсами пачки убывает по знакопеременному закону. Используемые методы: теории вероятности и математической статистики. Получены следующие результаты. Проведено оценивание точности измерения частоты пачки при наличии коррелированных фазовых флуктуаций ее радиоимпульсов. Выводы. Полученные результаты свидетельствуют о том, что для современных РЛС, в условиях регулярного измерения, на точность оценивания частоты пачки радиоимпульсов в значительно большей степени влияют статистические характеристики флуктуаций фаз, чем отношение сигнал-шум. Вследствие фазовых флуктуаций радиоимпульсов принятой пачки, среднеквадратическая ошибка измерения радиальной скорости аэродинамического объекта способна превышать значения, которые определяются требованиями к когерентноимпульсным РЛС. Дальнейшее направление исследований лежит в оценивании влияния случайных фазовых искажений рвдиолокационного сигнала на качество сопровождения аэродинамического объекта.

Ключевые слова: когерентно-импульсная радиолокационная станция; пачка радиоимпульсов; фазовые флуктуации; радиальная скорость аэродинамического объекта; гауссовый шум; радиолокационное наблюдение; эффективность оптимизации. 